\title{
Pain, kinesiophobia and quality of life of low back pain patients*
}

\author{
Dor, cinesiofobia e qualidade de vida de pacientes com dor lombar
}

\author{
Adriana Nascimento Silva ${ }^{1}$, Marielza Regina Ismael Martins ${ }^{1}$ \\ ${ }^{*}$ Received from School of Medicine of São José do Rio Preto, São José do Rio Preto, SP, Brazil.
}

DOI 10.5935/1806-0013.20140023

\section{ABSTRACT}

BACKGROUND AND OBJECTIVES: Chronic low back pain is a musculoskeletal problem with high prevalence and frequent associated conditions, which causes major impact on patients' daily life and quality of life. This study aimed at evaluating pain perception, fear of movement and adherence to treatment of patients with low back pain and surgical indication.

METHODS: This is a prospective study with convenience sample made up of low back pain patients, called test group: chronic non-cancer pain patients who were randomly selected and were waiting for surgery. Control group was made up of patients screened by the Pain Clinic, with low back pain, however asymptomatic. Tools were the visual analog scale, the Morisky \& Green questionnaire to check adherence to treatment and the Roland-Morris questionnaire to evaluate functional incapacity. Fear of movement was evaluated by the Tampa Scale for Kinesiophobia and quality of life by the Study Short form 12 Health Survey (SF-12) (Medical Outcomes).

RESULTS: Mean age of the test group was $38.8 \pm 6.5$ years with prevalence of females, impaired labor situation and mean education of $8.5 \pm 3.8$ years. Both mental and physical components had lower quality of life scores in the test group, in addition to more severe pain, functional incapacity and fear of movement. Non-adherence to treatment was seen in $65 \%$ of test group patients. CONCLUSION: Fear of movement, functional incapacity and pain observed in test group may have implications in the quality of life of low back pain patients who will be submitted to surgery and may be predictors for the incorporation of different strategies to contribute to more effective approaches.

Keywords: Evaluation, Low back pain, Quality of life.

1. School of Medicine of Sấo José do Rio Preto, Sâo José do Rio Preto, SP, Brazil.

Submitted in August 19, 2013.

Accepted for publication in May 12, 2014.

Conflict of interests: none. Sponsoring sources: Institutional Program of Scientific Initiation Scholarships (PIBIC)/Cnpq.

Correspondence to:

Marielza Regina Ismael Martins

Av. Brigadeiro Faria Lima, 5416

Dept $^{\circ}$ de Ciências Neurológicas

15090-000 São José do Rio Preto, SP, Brasil.

E-mail: marielzamartins@famerp.br

(c) Sociedade Brasileira para o Estudo da Dor

\section{RESUMO}

JUSTIFICATIVA E OBJETIVOS: A dor lombar crônica é um problema musculoesquelético com alta prevalência e frequentes condiçóes associadas, que causa grande impacto no cotidiano e na qualidade de vida dos pacientes. O objetivo deste estudo foi avaliar a percepção de dor, medo do movimento e adesáo ao tratamento em pacientes com dor lombar e indicação cirúrgica.

MÉTODOS: Trata-se de estudo prospectivo em amostra de conveniência composta por pacientes com dor lombar, denominado grupo teste: dor crônica de origem náo oncológica, escolhidos aleatoriamente e que estavam em fila de espera para realização de cirurgia. O grupo controle foi composto de pacientes triados na Clínica da Dor, com lombalgia, porém assintomáticos. Os instrumentos utilizados foram a escala visual analógica, o questionário de Morisky \& Green para verificar a adesão ao tratamento e o questionário Roland-Morris para avaliar a incapacidade funcional. O medo do movimento foi verificado pela Escala Tampa de Cinesiofobia e a qualidade de vida pelo Study Short Form 12 Health Survey (SF-12) (Medical Outcomes).

RESULTADOS: A média de idade do grupo teste foi de 38,8 $\pm 6,5$ anos prevalecendo o gênero feminino, situação laboral comprometida e escolaridade média de $8,5 \pm 3,8$ anos. Tanto o componente físico quanto o mental apresentaram menores escores de qualidade de vida no grupo teste, além de maior intensidade de dor, incapacidade funcional e medo do movimento. A não adesão ao tratamento farmacológico ocorreu em $65 \%$ do pacientes do grupo teste.

CONCLUSÁO: O medo do movimento, a incapacidade funcional e a dor verificados no grupo teste podem ter implicaçóes na qualidade de vida de pacientes com dor lombar que serão submetidos a intervenção cirúrgica e ser fatores preditores para que se incorporem estratégias diversas a fim de contribuir para condutas mais eficazes.

Descritores: Avaliação, Dor lombar, Qualidade de vida.

\section{INTRODUCTION}

Low back pain (LBP) is the second largest complaint worldwide and the major cause of temporary leave in Brazil ${ }^{1}$. Incapacity and poorer function are common among chronic low back pain patients and their quality of life (QL) depends more on the level of incapacity than on pain, as well as on costs ${ }^{2}$. Low back pain is any persistent pain in the lower spinal region for more than three months and which becomes chronic. Chronic LBP is one of the most common musculoskeletal 
disorders in industrialized societies, affecting 70 to $80 \%$ of the adult population in some moment of life, having predilection for young adults in economically active stage, and is one of the most common causes of absenteeism due to total or partial incapacity ${ }^{2,3}$.

Types of LBP may be classified according to their duration. Acute low back pain has sudden onset and lasts for less than six weeks, while sub-acute low back pain lasts from six to 12 weeks, and chronic low back pain lasts for more than 12 we$\mathrm{eks}^{4}$. One may state that chronic low back pain is characterized by disabling syndrome and pain which lasts for more than three months after the first acute pain episode, in addition to gradual installation of incapacity, very often with imprecise onset and periods of improvement and worsening ${ }^{3,4}$.

With regard to treatment, the first objective is pain relief. Many drugs may be used, including analgesics, anti-inflammatory drugs, myorelaxants, steroids and opioids, always after evaluating the risk-benefit of each one of them. Rest, although recommended in the acute stage, should be limited to a short period since its extension delays recovery and favors process chronicity, especially for favoring the loss of muscle strength ${ }^{5}$. No isolated therapy is efficient for chronic low back pain ${ }^{6}$ The same acute stage drugs may be used and, in some cases, there are major benefits with the use of some classes of antidepressants in low doses to control pain ${ }^{7}$. Rehabilitation with stretching and muscle strengthening exercises, in addition to postural reeducation, are critical to decrease symptoms and prevent pain recurrence. Other interventions include transcutaneous electric nerve stimulation (TENS), acupuncture, cognitive-behavioral therapy and infiltration. Corsets and girdles should only be used during acute crisis or when there is spinal instability. Their continuous use may lead to muscle hypotrophy generating a vicious cycle of pain ${ }^{8}$.

Only 1 to $2 \%$ of patients need surgery. The need to change life habits, be it with regard to physical activity, postural vices or passive attitude with relation to pain, should always be recommended. Low back pain treatment will be more effective if it is aimed at patients and not at their injuries or exams $s^{7,8}$. LBP has economic repercussions and causes suffering and QL limitations such as: difficulty to carry out activities, stress, irritability, hopelessness, sleep disorders, depression, fatigue and incapacities ${ }^{3}$, so a multidisciplinary approach is indicated and is being adopted by different treatment centers worldwide as an effective manner to treat chronic low back pain, substantially improving QL of people with such clinical presentation ${ }^{3,4}$.

The literature also reports that chronic LBP patients have more fear of movement, of physical activities and of exercising, and are more sensitive to pain and fearful of recurrence, so these studies emphasize that fear of movement should be early identified and treated in patients with chronic low back pain because they are predictors for poorer evolution ${ }^{9,10}$. In light of the above, this study aimed at comparing two LBP groups, with and without surgical indication, to better understand the profile, the differences and similarities of both groups, in order to provide more effective intervention measures for each group.

\section{METHODS}

This is a descriptive, exploratory, comparative, crossover study with quantitative approach carried out in the Pain Clinic Ambulatory, Base Hospital (FUNFARME/FAMERP). Individuals of both genders, with enough cognitive level to understand the procedures and to follow given guidance were included. All patients have signed the Free and Informed Consent Term (FICT). Patients with psychiatric disease and no clinical follow up in the Pain Clinic, Base Hospital were excluded.

Patients were allocated in two groups: test group (TG), with diagnosis of low back pain and surgical indication $(n=15)$, and control group (CG) $(n=20)$, with diagnosis of low back pain and no surgical indication. CG was made up of individuals paired by age and education level with regard to TG.

Patients of both groups were evaluated by the visual analog scale $(\mathrm{VAS})^{11}$, which consists in measuring pain intensity and is an important tool to check pain evolution during treatment and even at each medical visit in a more reliable way; Morisky \& Green test ${ }^{12}$ (MGT) to check adherence to treatment. MGT is made up of four questions to identify attitudes and behaviors with regard to drug ingestion, and which has been shown to be useful to identify patients adhering or not to treatment.

According to MGT protocol, patients with maximum score of four are considered adherent and those with three or less are considered non-adherent to treatment. One MGT limitation is that it evaluates just adherence to pharmacological treatment, not taking into consideration adherence to non- pharmacological treatment. To evaluate LBP patients' incapacity, $\mathrm{MGT}^{13}$ translated, adapted and validated was used. This questionnaire is made up of 24 items involving the domains of functional capacity, limitation by physical aspects, pain, general health status, vitality, social aspects, emotional aspects and mental health.

Each item has the value of one point being the result the sum of all checked items with minimum score of zero and maximum of 24, which translates total functional incapacity. The Study Short Form 12 Health Survey (SF-12) was also applied, which is a generic QL questionnaire which, although being shorter that SF-36, is still a valid alternative. This tool is a good option for population-based studies and also for tracking health problems. It has a structure based on 10 items, extracted from SF-36 domains and 2 items added to improve the estimate of the 2 components created as from SF-36. Results are normalized and expressed in components (physical and mental) through standard deviations of the American population mean ( $Z$ score with mean of $50 \pm 10)$. To evaluate fear of movement the Tampa Scale for Kinesiophobia (TSK) ${ }^{15}$ was used, for being one of the most popular tools currently used to evaluate kinesiophobia. This scale consists in a self-applicable questionnaire with 17 questions addressing pain and symptoms intensity. Scores vary from one to four points, being that the answer "totally disagree" is equivalent to one point, "partially disagree", to two points, "partially agree" to 
three points and "totally agree" to four points. To obtain the final score it is necessary to invert scores of questions 4, 8, 12 and 16. Final score may be at least 17 and at the utmost 68 points, being that the higher the score the higher the level of kinesiophobia.

For statistical analysis data were recorded in spreadsheets and analyzed by descriptive statistics. For questions with variables yes or no NcNemar test was used for comparison before and after, within each group and, between groups, possible yes and no combinations were evaluated. Quantitative variables were evaluated by the paired T test or Signal test, when recommended. In the case of inter-group analysis, $T$ test for 2 samples and Mann-Whitney test were used. Finally, ordinal variables were analyzed by non-parametric tests, being that Signal test was used within the same group and Mann-Whitney test to compare between groups. Results are shown in tables, figures and descriptively.

This study was approved by the Research Ethics Committee, FAMERP, under n. 2384/2010.

\section{RESULTS}

This study tried to identify good indicators of self-evaluation of low back pain patients with surgical indication to obtain a more complete profile of them and so provide more effective intervention measures. It was observed that in both groups there has been predominance of females, mean age of $38.8 \pm 6.5$ for TG and most of respondents of both groups had no integral labor activity or were on leave, or just had partial activity, which shows the interference of pain in labor activities. Table 1 shows characteristics of both groups.

Table 1. Characteristics of patients of both studied groups

\begin{tabular}{lcccc}
\hline Variables & Groups & $\mathrm{n}$ & $\begin{array}{c}\text { Mean } \pm \\
\text { SD }\end{array}$ & $\%$ \\
\hline $\begin{array}{l}\text { Age } \\
\text { (years) }\end{array}$ & TG & 15 & $38.8 \pm 6.5$ & \\
Gender & TG & 15 & $43.4 \pm 11.5$ & \\
& CG & 20 & & $\begin{array}{c}\text { Female } 73.4(\mathrm{n}=11) \\
\text { Male 26.6 }(\mathrm{n}=4)\end{array}$ \\
& & & & $\begin{array}{c}\text { Female } 60.0(\mathrm{n}=12) \\
\text { Male 40.0 }(\mathrm{n}=8)\end{array}$ \\
$\begin{array}{l}\text { Labor } \\
\text { situation }\end{array}$ & TG & 15 & & $\begin{array}{c}\text { Integral activity } 6.6(\mathrm{n}=1) \\
\text { Partial activity } 53.4(\mathrm{n}=8) \\
\text { On leave } 40.0(\mathrm{n}=6)\end{array}$ \\
& CG & 20 & & $\begin{array}{c}\text { Integral activity } 20.0(\mathrm{n}=4) \\
\text { Partial activity } 45.0(\mathrm{n}=9) \\
\text { On leave 35.0 }(\mathrm{n}=7)\end{array}$ \\
$\begin{array}{l}\text { Education } \\
\text { (years) }\end{array}$ & TG & 15 & $8.5 \pm 3.8$ & \\
\hline
\end{tabular}

TG: test group; CG: control group.

With regard to QL, the SF-12 questionnaire was used, which is a generic measurement and does not target a specific age group or group of diseases. Results are calculated using the scores of 12 questions, from zero to 100, where zero indicates low QL and 100 high QL levels. Results or our study are shown in figure 1. It is observed that both physical and mental health are impaired in TG. TG has lower QL as compared to CG in both components with statistically significant difference $(\mathrm{p}<0.05)$.

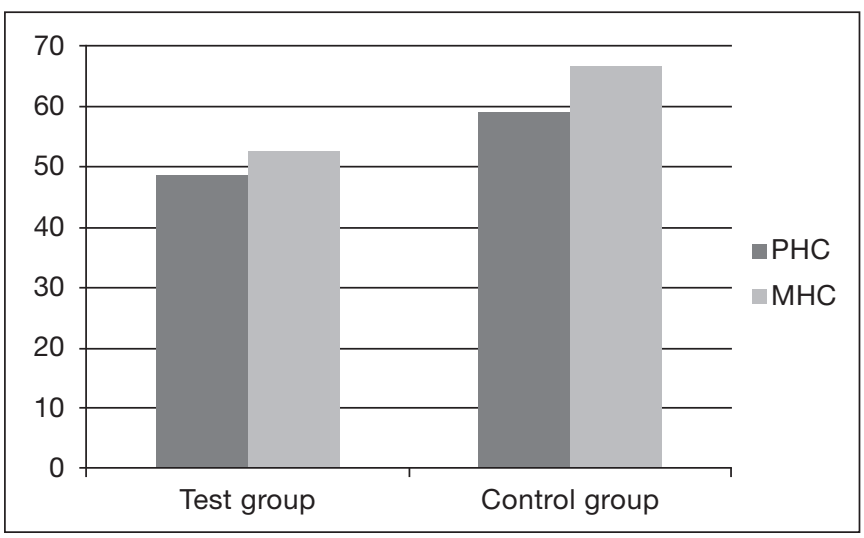

Figure 1. Total score of physical (PHC) and mental (MHC) health components of the generic quality of life questionnaire SF-12, comparing both groups

With regard to VAS, TG had higher scores, indicating more severe pain. In the Roland Morris questionnaire, which expresses daily and labor situations which may be impaired by low back pain, highest mean was $11.92 \pm 2.50$ with significant difference between groups $(\mathrm{p}<0.05)$. TSK, which measures fear of movement and of injury recurrence, has shown higher scores in TG with statistically significant difference (Table 2).

Table 2. Mean pain values for studied groups

\begin{tabular}{lcccc}
\hline Tools & Groups & $\mathrm{n}$ & Mean \pm SD & $\mathrm{p}$ value \\
\hline Visual analog scale & Test & 15 & $6.35 \pm 2.54$ & \\
& Control & 20 & $4.56 \pm 1.35$ & $0.048^{*}$ \\
Roland Morris & Test & 15 & $11.92 \pm 2.50$ & \\
& Control & 20 & $8.13 \pm 3.56$ & $0.035^{*}$ \\
Tampa scale for & Test & 15 & $46.0(20-65)$ & \\
kinesiophobia & Control & 20 & $38.0(22-56)$ & $0.035^{\star}$ \\
\hline TG: test group; CG: control group; ${ }^{*}$ statistically significant difference $p<0.05$.
\end{tabular}

From TG patients evaluated by MGT 65\% (n=9) have not adhered to prescribed pharmacological treatment. The relationship between MGT and gender has not shown statistically significant difference ( $p>0.05)$.

\section{DISCUSSION}

The identification of biopsychosocial and QL factors in LBP patients who will be submitted to surgery allows for a more effective treatment very often decreasing complication rates. Our study has observed the prevalence of females aged between 32 and 60 years and with impaired labor situation.

Studies ${ }^{16,17}$ confirm such results which show that lumbar spine musculoskeletal disorders are major public health problems. So, intervention strategies should be developed to control such morbidity. 
Authors report that approximately $50 \%$ of females have some type of pain, especially low back pain ${ }^{17}$, often observed in those remaining standing up or sitting down for long periods. Females, who are majority in this study, may have presented more pain complaints probably due to some anatomo-functional characteristics, such as less bone mass, lower muscle resistance and more unstable joints, and also because their muscle strength is in average $30 \%$ weaker as compared to males. Some studies ${ }^{17,18}$ show that the younger the age the lower the chance of having LBP, observing that with age there is higher prevalence of low back pain.

With regard to pain during activities, observed with TSK, this study has shown more fear in TG. Some authors ${ }^{18,19}$ try to explain that little is known about the exact mechanism and factors influencing LBP chronicity, and report that the model based on clinical signs and symptoms indicates that pain is proportional to tissue injury extension.

However, there are evidences that the persistence of pain symptoms cannot be explained only by objective clinical findings and, for this condition, an approach purely based on clinical model may be insufficient. They also report that some individuals with musculoskeletal pain develop chronic pain syndrome, the cognitive model of fear of movement/ (re) injury proposed by Vlaeyen et al. ${ }^{20}$, which is based on fear of pain, or more specifically, fear that physical activities may cause pain and/or injury recurrence.

Two opposite behavioral responses are proposed, being that confronters face pain in the attempt of improving and believe that the presence of pain does not justify the limitation of their functional activities, while avoiders have fear of movement and believe that activity is directly related to the presence of pain. This avoiding behavior may lead to physical and psychological disorders which will contribute to the chronicity of pain.

McCracken and Turk ${ }^{21}$ have also reported that LBP individuals with surgical indication have solicitude behaviors which encourage rest and stimulate such patients to decrease activities, reinforcing avoidance behaviors, which increase the risk of dependence and incapacity and impairs QL.

In analyzing non-pharmacological adherence of most TG patients, there are reports that this factor is a major challenge both for the government and health professionals, because it depends on the implementation of multidisciplinary programs in all levels of assistance for interventions to be more effective ${ }^{22}$.

\section{CONCLUSION}

Fear of movement, functional incapacity and pain observed in TG may have implications in the QL of LBP patients who will be submitted to surgery.
Evaluating such patients with different tools may give the health team the real dimension of symptoms, taking into consideration all these factors for the implementation of health assistance models which incorporate different individual and collective strategies to contribute to more effective approaches.

\section{REFERENCES}

1. Lin CW, Haas M, Maher CG, Machado LA, van Tulder MW. Cost-effectiveness of guideline-endorsed treatments for low back pain: a systematic review. Eur Spine J. 2011;20(7):1024-38

2. Al-Obaidi SM, Al-Zoabi B, Al-Shuwaie N, Al-Zaabie N, Nelson RM. The influence of pain and pain-related fear and disability beliefs on walking velocity in chronic low back pain. Int J Rehabil Res. 2003;26(2):101-8.

3. Brazil AV, Ximenes AC, Radu AS, Fernades AR, Appel C, Maçaneiro CH, et al. Diagnóstico e tratamento das lombalgias e lombociatalgias. Rev Bras Reumatol. 2004;44(6):419-25.

4. Martins MR, Foss MH, Santos Junior R, Zancheta M, Pires IC, Cunha NA, et al A eficácia da conduta do grupo de postura em pacientes com lombalgia crônica. Rev Dor. 2010;11(2):105-10.

5. Melloh M, Roder C, Elfering A, Theis JC, Muller U, Staub LP, et al. Differences across health care systems in outcome and cost-utility of surgical and conservative treatment of chronic low back pain: a study protocol. BMC Musculoskelet Disord. 2008;9(1):81-9

6. Grotle M, Foster NE, Dunn KM, Croft P. Are prognostic indicators for poor outcome different for acute and chronic low back pain consulters in primary care? Pain. 2010;151(3):790-7.

7. Mekhail N, Costandi S, Abraham B, Samuel SW. Functional and patient-reported outcomes in symptomatic lumbar spinal stenosis following percutaneous decompression. Pain Pract. 2012;12(6):417-25.

8. Spoor AB, Oner FC. Minimally invasive spine surgery in chronic low back pain patients. J Neurosurg Sci. 2013;57(3):203-18.

9. de Moraes Vieira EB, de Góes Salvetti M, Damiani LP, de Mattos Pimenta CA. Self-efficacy and fear avoidance beliefs in chronic low back pain patients: coexistence and associated factors. Pain Manag Nurs. 2013;S1524-9042. [Epub ahead of print].

10. Lüning Bergsten C, Lundberg M, Lindberg P, Elfving B. Change in kinesiophobia and its relation to activity limitation after multidisciplinary rehabilitation in patients with chronic back pain. Disabil Rehabil. 2012;34(10):852-8

11. Pimenta CAM. Escalas de avaliaçáo de dor. In: Teixeira MD, (editor). Dor conceitos gerais. São Paulo: Limay; 1994. 46-56p.

12. Morisky DE, Green LW, Levine DM. Concurrent and predictive validity of a self reported measure of medication adherence. Med Care. 1986;24(1):67-73.

13. Nusbaum L, Natour J, Ferraz MB, Goldenberg J. Translation, adaptation and validation of the Roland-Morris questionnaire--Brazil Roland-Morris. Braz J Med Biol Res. 2001;34(2):203-10.

14. Andrade TL, Camelier AA, Rosa FW, Santos MP, Jezler S, Pereira e Silva JL. Aplicability of the 12-Item Short-Form Health Survey in patients with progressive systemic sclerosis. J Bras Pneumol. 2007;33(4):414-22.

15. Siqueira FB, Teixeira-Salmela LF, Magalhães LC. Análise das propriedades psicométricas da versão brasileira da escala tampa de cinesiofobia. Acta Ortop Bras. 2007;15(1):19-24.

16. Fanian H, Ghassemi GR, Jourkar M, Mallik S, Mousavi MR. Psychological profile of Iranian patients with low-back pain. East Mediterr Health J. 2007;13(2):335-46

17. Antunes RS, Macedo BG, Amaral TS, Gomes HA, Pereira LS, Rocha FL. Dor e cinesiofobia e qualidade de vida em pacientes com lombalgia crônica e depressăo. Acta Ortop Bras. 2013;21(1):27-9.

18. Atalay A, Arslan S, Dinçer F. Psychosocial function, clinical status, and radiographic findings in a group of chronic low back pain patients. Rheumatol Int. 2001;21(2):62-5.

19. Boersma K, Linton SJ. Psychological processes underlying the development of a chronic pain problem: a prospective study of the relationship between profiles of psychological variables in the fear-avoidance model and disability. Clin J Pain. 2006;22(2):160-6.

20. Vlaeyen JW, Kole-Snijders AM, Boeren RG, van Eek EH. Fear of movement/(re) injury in chronic low back pain and its relation to behavioral performance. Pain. 1995;62(3):363-72.

21. McCracken LM, Turk DC. Behavioral and cognitive-behavioral treatment for chronic pain: outcome, predictors of outcome and treatment process. Spine. 2002;27(22):2564-73.

22. Foss MH, Martins MRI, Ikehara E, Rampazo F, Tinti G, Detoni M, et al. Quality of life of employees with low back pain. Rev Dor. 2009;10(2):106-12. 